\title{
Optimum Collector Tilt Angles For Low Latitudes
}

\author{
C.O.C. Oko* and S.N. Nnamchi
}

Department of Mechanical Engineering University of Port Harcourt, PMB 5323, Port Harcourt, Nigeria

\begin{abstract}
Determination of the optimum collector tilt angles for low latitudes is the main subject of this paper. The monthly, seasonal and yearly average daily values of insolation were calculated for tilt angles ranging from $0-40^{\circ}$. Microsoft Excel was used to fit equations on monthly, seasonal and yearly average daily insolation with respect to tilt angles. The calculus method of optimization was employed to establish the optimum tilt angle for low latitudes, 4.86$13.02{ }^{\circ} \mathrm{N}$, spanning the territory of Nigeria. Expressions for the optimum tilt angles with respect to the low latitudes were also obtained. The results obtained compare favourable with those in literature and are useful for designing solar equipment in the range of the low latitudes considered in this study.
\end{abstract}

Keywords: Solar radiation, flat-plate solar collector, optimum tilt angles, low latitudes, solar energy.

\section{INTRODUCTION}

The intensity of extraterrestrial solar radiation on earth's horizontal and tilted surfaces is reduced by clouds, dusts and shades. Thus, the insolation reaching the earth's surface which is made up of the beam (or direct), diffuse (or scatter) and ground reflected radiations, depends on the cloudiness or clearness of the sky, which in turn depends on the season of the year [1-5]. However, harnessing the insolation to optimum level is of primary interest to solar design engineers in designing solar equipment.

Several factors affect the performance of the flat plate solar collectors: the angle of latitude, the declination angle, the slope angle, the sunrise or sunset hour angle and the azimuth angle [6]. However, the angle of latitude, the declination angle, the sunrise or sunset angle and the sunrise or sunset hour are controlled by nature whereas man controls the tilt and azimuth angles [7-9]. It has been established that the optimum performance of flat-plate solar collector occurs at azimuth angle of zero for south facing flat-plate solar collector [1]. Proper determination of tilt angle is essential in order to maximize: the insolation on the absorber plate, the working fluid temperature, and the collector and thermal efficiencies of solar equipment [10].

Solar trackers have been developed for tracking the solar path and adjusting the collector tilt angle accordingly for the purpose of maximizing solar energy from the sun. Although, tracking is the most efficient means of solar radiation energy collection, it is costly, energy demanding for its operation and does not suit all solar equipment [11]. Thus, emphasis is laid on the collector optimal tilt angle to achieve maximum insolation on tilted surfaces. This collector tilt angle may be permanently fixed, or adjusted monthly or seasonally [12].

*Address correspondence to this author at the Department of Mechanical Engineering University of Port Harcourt, PMB 5323, Port Harcourt, Nigeria; Tel: +234 8035536916; E-mail: chika.oko@uniport.edu.ng
Several propositions for the optimum tilt angle exist in the literature. For example, Wenger and Oliveira [13] proposed that the optimum tilt angle should commensurate with the latitude of the location; Fagbenle [14] proposed that for latitudes below $8.5^{\circ}$, the optimum tilt angle should be the latitude plus $10^{\circ}$, otherwise, the latitude plus $5^{\circ}$; Qiu and Riffat [15] proposed that the optimum tilt angle should be the latitude plus $10^{\circ}$. It is therefore necessary to find out which tilt angles are the optimal for the low latitudes of $\mathrm{Ni}$ geria, $4.86-13.02\left[{ }^{\circ} \mathrm{N}\right]$.

This paper, therefore, aims to establish the true optimum tilt angle for the low latitudes of Nigeria, $4.86-13.02\left[{ }^{\circ} \mathrm{N}\right]$, which maximizes the insolation on a tilted surface, and to provide expressions for predicting monthly, seasonal and yearly optimum tilt angles for the range of latitude considered.

\section{THE GOVERNING EQUATIONS}

The relevant equations are as follows $[1,6]$ :

The declination (i.e. the angular position of the earth-sun at solar noon with respect to the plane of equator), $\delta$, is given as

$\delta=23.45 \sin \left(360\left(\frac{284+\mathrm{n}}{365}\right)\right)$

where $n$ is number of days starting from 1st January to the given date.

The tilt angle (i.e. the angle between the horizontal and the tilted surface), $s$, is given by Wenger and Oliveira [13] and Fagbenle [14], respectively, as

$\mathrm{s}=\phi$

or, $\mathrm{s}=\phi+10^{\circ}$, for $0^{\circ}<\phi<8.5^{\circ}$, or $\mathrm{s}=\phi+5^{\circ}$, for $\phi>8.5^{\circ}$

The sunrise hour angle, $\omega_{s}$, is given as 
$\omega_{\mathrm{s}}=\cos ^{-1}(-\tan \delta \tan (\phi-\mathrm{s})), \operatorname{sign}(\delta)=\operatorname{sign}(\phi)$

or, $\omega_{\mathrm{s}}=\cos ^{-1}(-\tan \delta \tan \phi), \operatorname{sign}(\delta) \neq \operatorname{sign}(\phi)$

where $\operatorname{sign}(\mathrm{x})$ is the $\operatorname{sign}$ of $x$.

The monthly average daily extraterrestrial radiation incident on a horizontal surface, $\mathrm{H}_{0}$, is given as

$\mathrm{H}_{0}=\frac{24}{\pi} \mathrm{I}_{\mathrm{sc}}\left(\left[1+0.033 \cos \left(\frac{360 \mathrm{n}}{365}\right)\right]\left[\cos \phi \cos \delta \sin \omega_{\mathrm{s}}+\frac{2 \pi \omega_{\mathrm{s}}}{360} \sin \phi \sin \delta\right]\right)(4)$

where $I_{s c}$, is the solar constant.

The hourly cloudiness index, $\mathrm{K}_{\mathrm{T}}$, is given as

$\mathrm{K}_{\mathrm{T}}=\mathrm{a}+\mathrm{b}\left(\frac{\mathrm{n}}{\mathrm{N}}\right)$

where $a$ and $b$ are the cloudiness constants whose values depend on the locality; $n / N$ is the relative sunshine; and $\mathrm{N}=365$ days.

The monthly average daily total global insolation on a horizontal surface, $\mathrm{H}$, is given as

$$
\mathrm{H}=\mathrm{K}_{\mathrm{T}} \mathrm{H}_{0}
$$

The monthly average daily diffused insolation on the horizontal surface, $\mathrm{H}_{\mathrm{d}}$, according to Liu and Jordan [16] is correlated as

$\frac{\mathrm{H}_{\mathrm{d}}}{\mathrm{H}}=1.271-2.7604 \frac{\mathrm{H}}{\mathrm{H}_{0}}+1.8036\left(\frac{\mathrm{H}}{\mathrm{H}_{0}}\right)^{2}$

The monthly average daily solar beam contribution to the global insolation on a horizontal surface, $\mathrm{H}_{b}$, is

$\mathrm{H}_{\mathrm{b}}=\mathrm{H}-\mathrm{H}_{\mathrm{d}}$

The overall correction factor, $R$, is

$\mathrm{R}=\left(1-\frac{\mathrm{H}_{\mathrm{d}}}{\mathrm{H}}\right) \mathrm{R}_{\mathrm{b}}+\frac{\mathrm{H}_{\mathrm{d}}}{\mathrm{H}} \mathrm{R}_{\mathrm{d}}+\rho_{\mathrm{gr}} \mathrm{R}_{\mathrm{r}}$

where $\rho_{g r}$ is the effective ground reflectance and $R_{b}$ is the ratio of the beam insolation on tilted surface to that on horizontal surface and is given as

$\mathrm{R}_{\mathrm{b}}=\frac{\cos (\phi-\mathrm{s}) \cos (\delta) \cos (\omega)+\sin (\phi-\mathrm{s}) \sin (\delta)}{\cos \phi \cos \delta \cos \omega+\sin \phi \sin \delta}$

$s$ and $\omega$ are the tilt angle and hour angle, respectively; and $R_{d}$ is the ratio of the diffuse insolation on a tilted surface to that on a horizontal surface and is given as

$\mathrm{R}_{\mathrm{d}}=\cos ^{2}\left(\frac{\mathrm{s}}{2}\right)$

and $R_{r}$ is the radiative configuration factor from the ground and surroundings to the tilted surface:
$\mathrm{R}_{\mathrm{r}}=\sin ^{2}\left(\frac{\mathrm{s}}{2}\right)$

The monthly average daily global insolation on tilted surface, $H_{T}$, is

$\mathrm{H}_{\mathrm{T}}=\mathrm{HR}$

The insolation reaching the absorber plate, $q_{s}$, is given as

$\mathrm{q}_{\mathrm{s}}=\mathrm{H}_{\mathrm{T}} \tau_{\mathrm{c}} \alpha$

where $\tau_{c}$ and $\alpha$ are the transmittance and absorptance, respectively, and their product is given as

$\tau_{\mathrm{c}} \alpha=\frac{2 \alpha \mathrm{re}^{-\mathrm{k}_{\mathrm{c}} \ell_{\mathrm{c}}}}{\left(\mathrm{r}^{2}+1\right)\left[1-(1-\alpha) \rho_{\mathrm{gr}}\right]}$

where $r, k_{c}$, and $l_{c}$ are the refractive index of the cover plate, the extinction coefficient for the cover glass and the thickness of glass cover, respectively.

\section{THE OPTIMUM TILT ANGLE}

The data for the insolation reaching the absorber plate, $\mathrm{q}_{\mathrm{s}}$, is expressed as a quadratic function of the tilt angle, s, so that its optimum value $\mathrm{q}_{\mathrm{s}}^{*}$ is obtained at the stationary point:

$\frac{\mathrm{dq}_{\mathrm{s}}}{\mathrm{ds}}=0$

where

$\mathrm{q}_{\mathrm{s}}=\mathrm{c}_{0}+\mathrm{c}_{1} \mathrm{~s}+\mathrm{c}_{2} \mathrm{~s}^{2}$

$c_{i}, i=0,1,2$, are constant coefficients.

Differentiating Equation (17) and substituting into Equation (16), the optimum tilt angle, $s^{*}$, is found to be

$\mathrm{s}^{*}=\frac{\mathrm{c}_{1}}{2 \mathrm{c}_{2}}$

and the optimum insolation, $q_{s}^{*}$, becomes

$\mathrm{q}_{\mathrm{s}}^{*}=\mathrm{c}_{0}+\mathrm{c}_{1} \mathrm{~s}^{*}+\mathrm{c}_{2}\left(\mathrm{~s}^{*}\right)^{2}$

\section{RESULTS AND DISCUSSION}

The following input parameters are specified:

i. The solar constant, $I_{S C}=1353\left[\mathrm{~W} / \mathrm{m}^{2}\right]$.

ii. The hour angles, $\omega$, are tabulated in Table $\mathbf{1}$

iii. The azimuth angle, $\gamma=0$ for south facing flat plate collectors.

iv. Number of days $(n)$ starting from 1 st January to 15 th February, $n=45$ days.

v. The values for cloudiness constants, $a$ and $b$, and the relative sunshine, $n / N$, for the latitudes considered here are given by Fagbenle [14] 
Table 1. The Hour Angle, $\omega$, as a Function of the Hour of the Day

\begin{tabular}{|c|c|c|c|c|c|c|c|c|c|}
\hline Hour & $\mathbf{8 : 0 0}$ & $\mathbf{9 : 0 0}$ & $\mathbf{1 0 : 0 0}$ & $\mathbf{1 1 : 0 0}$ & $\mathbf{1 2 : 0 0}$ & $\mathbf{1 3 : 0 0}$ & $\mathbf{1 4 : 0 0}$ & $\mathbf{1 5 : 0 0}$ & $\mathbf{1 6 : 0 0}$ \\
\hline \hline$\omega\left[^{\circ}\right]$ & +60 & +45 & +30 & +15 & 0 & -15 & -30 & -45 & -60 \\
\hline
\end{tabular}

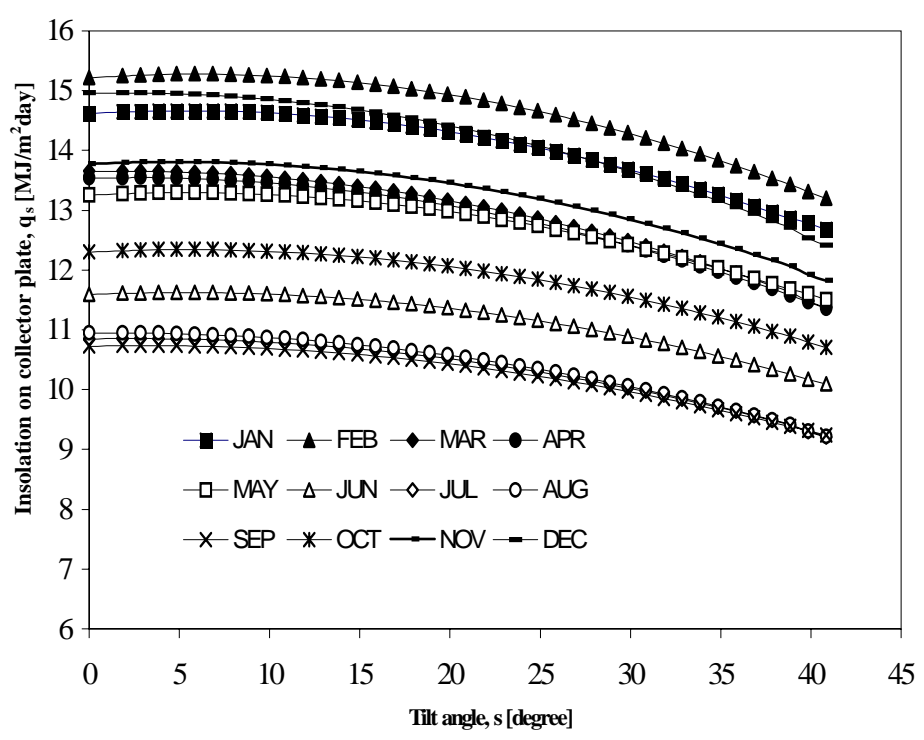

Fig. (1). Monthly average daily insolation on a south facing collector for Port Harcourt (latitude of $4.858^{\circ} \mathrm{N}$ ).

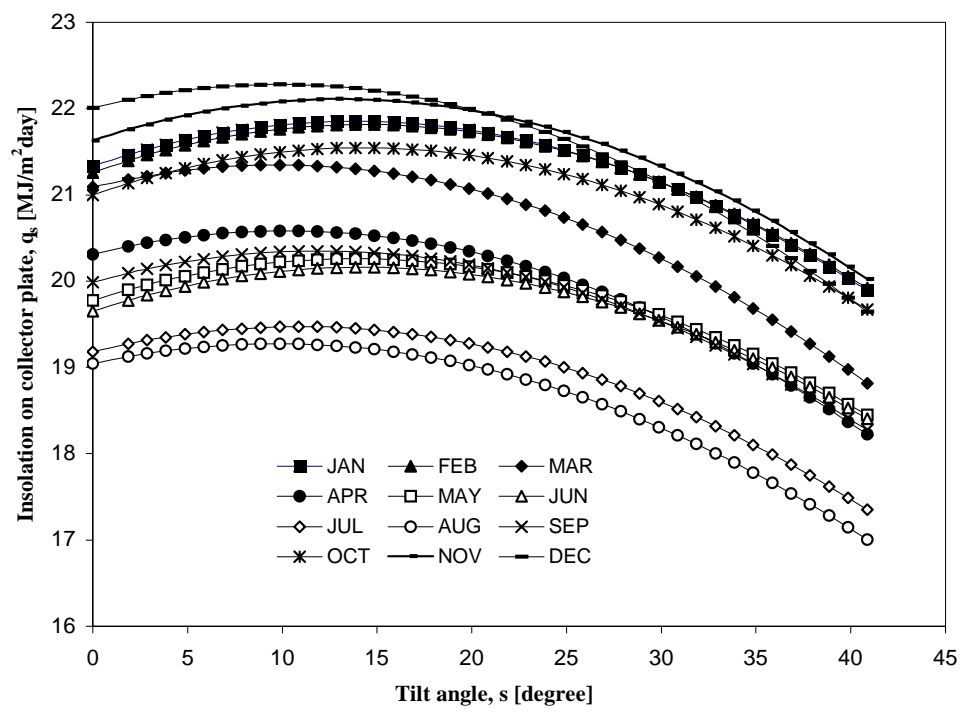

Fig. (2). Monthly average daily insolation on a south facing collector for Sokoto (latitude of $13.017^{\circ} \mathrm{N}$ ).

vi. The ground reflectance, $\rho_{g r}=0.2$, according to Liu and Jordan [16].

vii. The refractive index of the cover plate, $r=1.52$ for glass.

viii. The absorptance of the absorber, $\alpha=0.95$ for smooth aluminium.

ix. The thickness of the cover glass, $\ell_{\mathrm{c}}=0.004[\mathrm{~m}]$.

x. The extinction coefficient for the cover glass, $k_{c}=20$ $\left[m^{-1}\right]$.

xi. The cities considered are: Port Harcourt, Enugu, Makurdi, Lokoja, Minna, Bauchi, Maiduguri and Sokoto, which are located in the latitudes of 4.858, 6.467,
$7.700,8.800,9.617,10.333,11.850$ and $13.017\left[{ }^{\circ} \mathrm{N}\right]$, respectively.

These input data were used to compute the monthly, seasonal and yearly average daily insolation on a tilted surface, Equation (14), for latitudes ranging from 4.858 to $13.017^{\circ} \mathrm{N}$. Figs. (1, 3 and 5) show the monthly, seasonal and yearly dependence of the insolation reaching the tilted surface for Port Harcourt, the least latitude; and Figs. (2, 4 and 6) show the monthly, seasonal and yearly dependence of the insolation reaching the tilted surface for Sokoto, the highest latitude. It is seen from these plots that the insolation increases from tilt angle of zero to the latitude plus or minus $2^{\circ}$, and then decreases with further increase in the tilt angle. Fig. (7), the monthly optimum insolation, for the cities considered, 


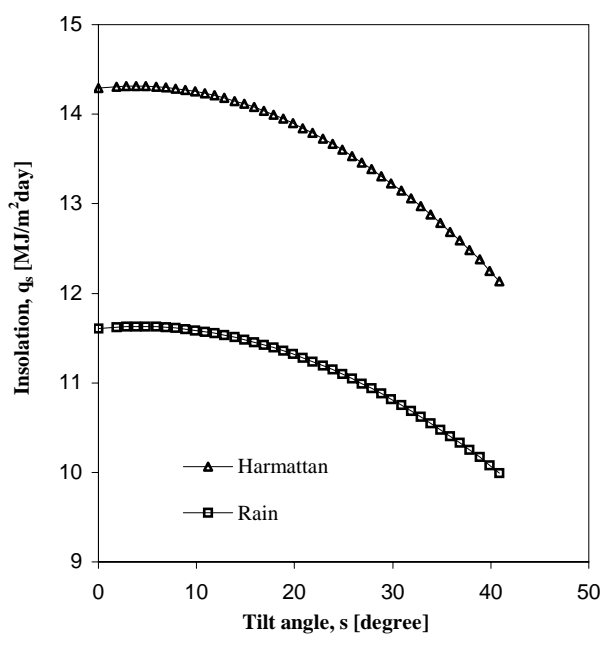

Fig. (3). Seasonal average daily insolation on tilted surface for Port Harcourt (latitude $=4.858^{\circ} \mathrm{N}$ ).

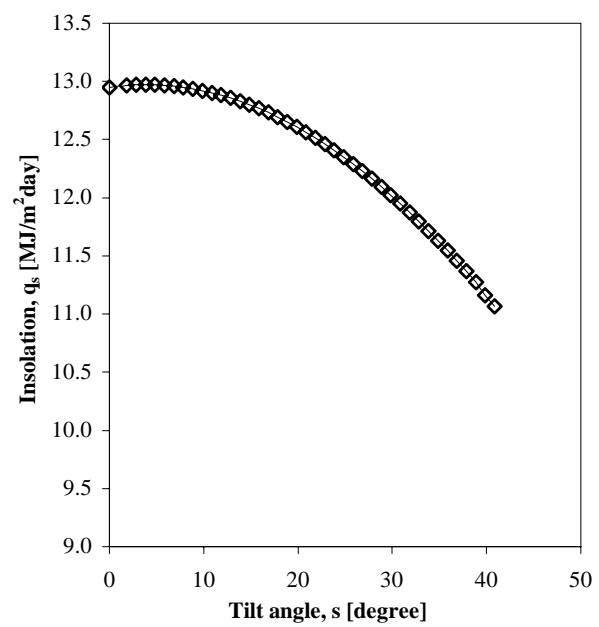

Fig. (4). Seasonal average daily insolation on tilted surface for Sokoto (latitude $=13.017^{\circ} \mathrm{N}$ ).

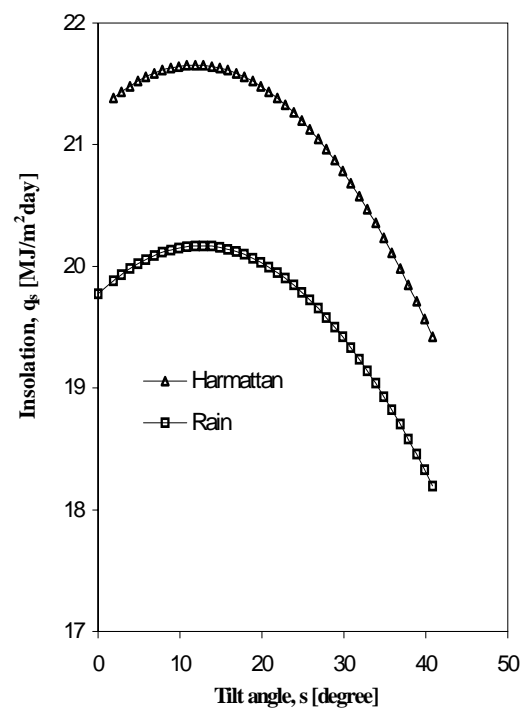

Fig. (5). Yearly average daily insolation on tilted surface for Port Harcourt (latitude $=4.858^{\circ} \mathrm{N}$ ).

shows that the solar insolation in June, July and August is at its lowest value. Thus, these months will not favour collection of solar energy because of poor climatic conditions (low

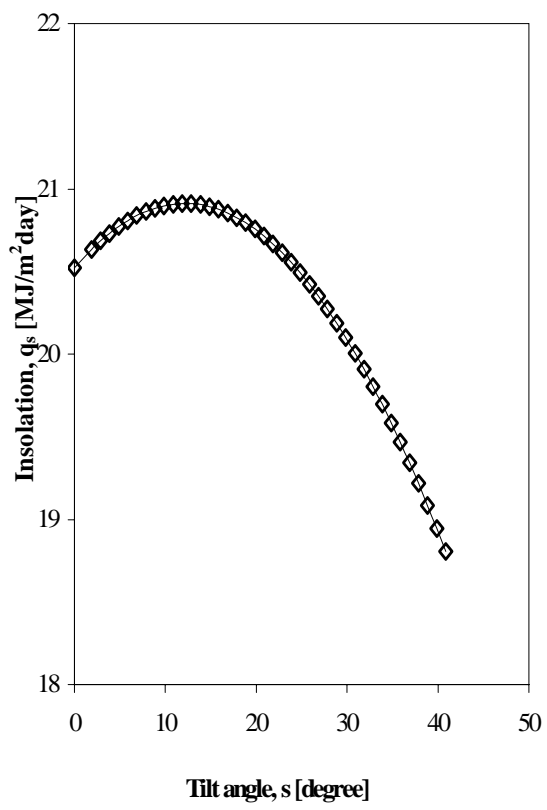

Fig. (6). Yearly average daily insolation on tilted surface for Sokoto (latitude $=13.017^{\circ} \mathrm{N}$ ).

relative sunshine). Therefore, solar drying of agricultural products will not be favoured in this period of the year because it is the peak of the rain season.

The dependence of the insolation on a tilted surface for these cities is fitted as a quadratic function, Equation 17, using Microsoft Excel. The values of the coefficients, $c_{i}$, of Equation (17), are tabulated in Tables (A1) and (A2) of the Appendix; they are useful for determining the monthly, seasonal and yearly optimum tilt angles, $s$, Equation (18) by the calculus method (using Equation 16). The results obtained from the monthly, seasonal and yearly analysis for the eight Nigerian cities considered showed that the optimum tilt angle varies with latitude of the location, Tables (2) and (3). The monthly optimum tilt angles, Table (2), produce the largest annual cumulative insulation; this is followed by the seasonal optimum tilt angles, Table (3). That is, by varying the tilt angle of the fixed flat plate collector every month to their monthly optimum angle, the solar energy collected per year will be more than that collected per year when the tilt angle of the collector is changed twice (seasonally) a year to their seasonal optimum. Of course, the least solar energy harvest is realised when the collector tilt angle is permanently fixed to their yearly optimum angle.

Table (3) also compares the seasonal and yearly optimum tilt angles and their corresponding values of insolation obtained in this work with those of Wenger and Oliveira [13], and Fagbenle [14]. It is seen that the results obtained in this work are better, and thus, the optimum tilt angle for a specified low latitude is neither equal to the latitude of the location nor equal to the latitude plus $10^{\circ}$ as suggested by Wenger and Oliveira [13], and Fagbenle [14], respectively, Equations (2a) and (2b). However, the deviation of the optimum tilt angles from the latitudes of the locations considered in the present work is approximately $\pm 2^{\circ}$.

Mathematical expressions correlating the optimum tilt angle with latitude are presented in Tables (4) and (5) for the monthly, and seasonal and yearly cases, respectively. 


\section{APPENDIX A; Tabulated Data}

Table A1. Coefficients in the Equation for the Monthly Insolation, Equation (17), $\mathbf{q}_{\mathrm{s}}\left[\mathrm{MJ} / \mathrm{m}^{2} \mathrm{day}\right]$

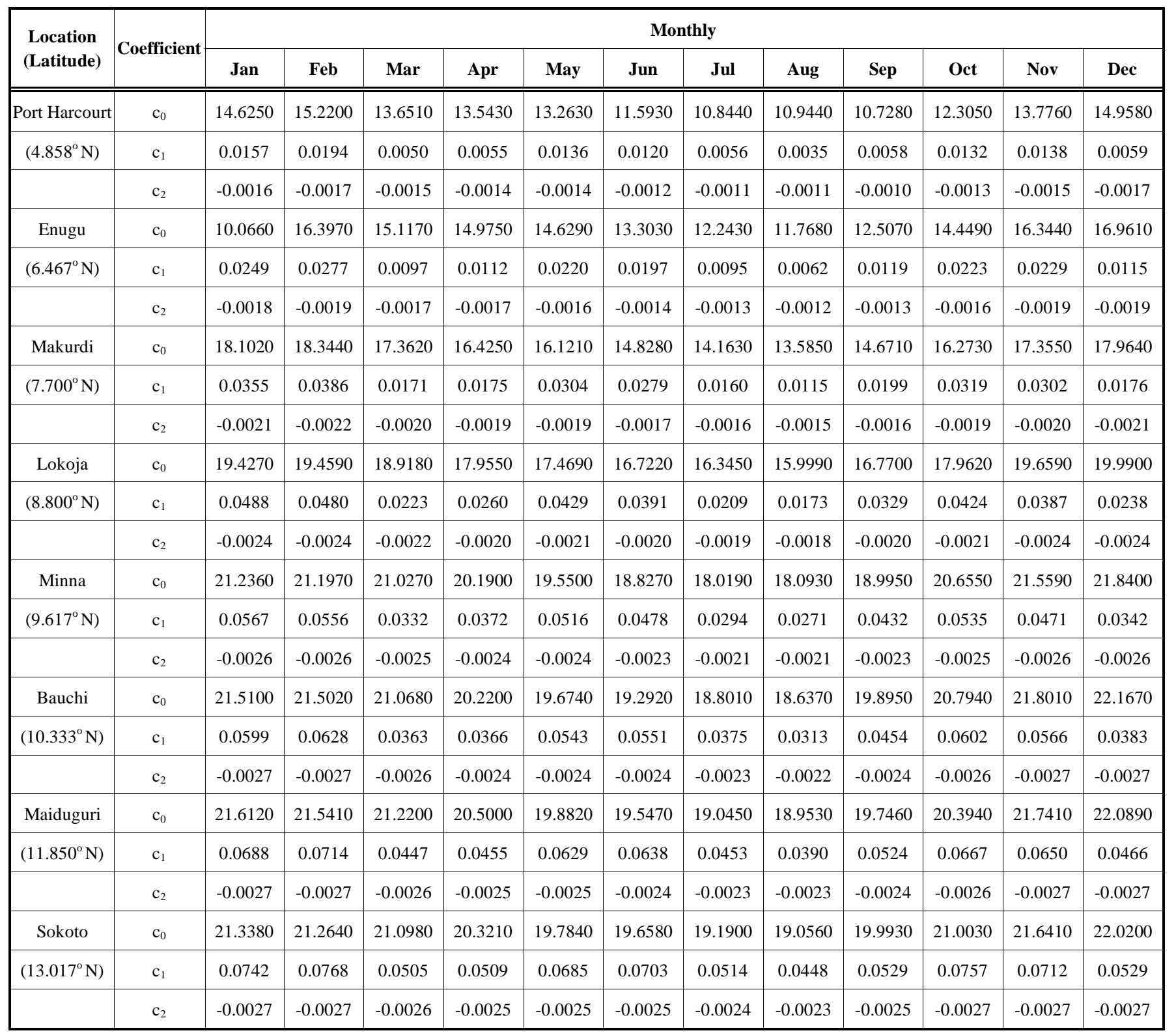

Table A2. Coefficients in the Equation for the Seasonal and Yearly Global Solar Radiation, Equations (17), $\mathbf{q}_{\mathrm{s}}\left[\mathrm{MJ} / \mathrm{m}^{2} \mathrm{day}\right]$

\begin{tabular}{|c|c|c|c|c|}
\hline \multirow{2}{*}{$\begin{array}{c}\text { Location } \\
\text { (Latitude) }\end{array}$} & \multirow{2}{*}{ Const } & \multicolumn{2}{|c|}{ Seasonal } & \multirow{2}{*}{ Yearly } \\
\cline { 3 - 5 } & & Harmattan & 11.6120 & 12.9540 \\
\hline \hline Port Harcourt & $c_{0}$ & 14.2950 & 0.0090 & 0.0100 \\
\hline$\left(4.858^{\circ} \mathrm{N}\right)$ & $\mathrm{c}_{1}$ & 0.0109 & -0.0012 & -0.0014 \\
\hline & $\mathrm{c}_{2}$ & -0.0016 & 13.1490 & 14.5630 \\
\hline Enugu & $\mathrm{c}_{0}$ & 15.9760 & 0.0153 & 0.0167 \\
\hline$\left(6.467^{\circ} \mathrm{N}\right)$ & $\mathrm{c}_{1}$ & 0.0181 & -0.0014 & -0.0016 \\
\hline & $\mathrm{c}_{2}$ & -0.0018 & 14.9400 & 16.2650 \\
\hline$\left(7.700^{\circ} \mathrm{N}\right)$ & $c_{0}$ & 17.5910 & 0.0230 & 0.0246 \\
\hline
\end{tabular}


Table A2. cont...

\begin{tabular}{|c|c|c|c|c|}
\hline $\begin{array}{c}\text { Location } \\
\text { (Latitude) }\end{array}$ & Const & \multicolumn{2}{|c|}{ Seasonal } & Yearly \\
\hline Lokoja & $\mathrm{c}_{0}$ & 19.2380 & 16.8780 & 18.0570 \\
\hline$\left(8.800^{\circ} \mathrm{N}\right)$ & $\mathrm{c}_{1}$ & 0.0344 & 0.0326 & 0.0336 \\
\hline Minna & $\mathrm{c}_{0}$ & 21.1770 & 19.0220 & 20.0980 \\
\hline \multirow[t]{2}{*}{$\left(9.617^{\circ} \mathrm{N}\right)$} & $\mathrm{c}_{1}$ & 0.0438 & 0.0422 & 0.0431 \\
\hline & $\mathrm{c}_{2}$ & -0.0026 & -0.0023 & -0.0024 \\
\hline Bauchi & $\mathrm{c}_{0}$ & 21.3470 & 19.5150 & 20.4320 \\
\hline Maiduguri & $\mathrm{c}_{0}$ & 21.4520 & 19.5940 & 20.5220 \\
\hline \multirow[t]{2}{*}{$\left(11.850^{\circ} \mathrm{N}\right)$} & $\mathrm{c}_{1}$ & 0.0568 & 0.0551 & 0.0561 \\
\hline & $\mathrm{c}_{2}$ & -0.0027 & -0.0024 & -0.0025 \\
\hline Sokoto & $\mathrm{c}_{0}$ & 21.2820 & 19.7800 & 20.5320 \\
\hline \multirow[t]{2}{*}{$\left(13.017^{\circ} \mathrm{N}\right)$} & $\mathrm{c}_{1}$ & 0.0626 & 0.0617 & 0.0621 \\
\hline & $\mathrm{c}_{2}$ & -0.0027 & -0.0025 & -0.0026 \\
\hline
\end{tabular}

Table 2. Monthly Average Optimum Tilt Angles [Degree]

\begin{tabular}{|c|c|c|c|c|c|c|c|c|c|c|c|c|c|}
\hline \multirow{2}{*}{ Location } & \multirow{2}{*}{$\begin{array}{c}\text { Latitude } \\
{\left[{ }^{\circ} \mathbf{N}\right]}\end{array}$} & \multirow[b]{2}{*}{ Jan } & \multirow[b]{2}{*}{ Feb } & \multirow[b]{2}{*}{ Mar } & \multirow[b]{2}{*}{ Apr } & \multirow[b]{2}{*}{ May } & \multirow{2}{*}{$\begin{array}{c}\text { Monthly } \\
\text { Jun }\end{array}$} & \multirow[b]{2}{*}{ Jul } & \multirow[b]{2}{*}{ Aug } & \multirow[b]{2}{*}{ Sep } & \multirow[b]{2}{*}{ Oct } & \multirow[b]{2}{*}{ Nov } & \multirow[b]{2}{*}{ Dec } \\
\hline & & & & & & & & & & & & & \\
\hline Port Harcourt & 4.858 & 4.906 & 5.706 & 1.667 & 1.964 & 4.857 & 5.000 & 2.545 & 1.591 & 2.900 & 5.077 & 4.600 & 1.735 \\
\hline Enugu & 6.467 & 6.917 & 7.289 & 2.853 & 3.294 & 6.875 & 7.036 & 3.654 & 2.583 & 4.577 & 6.969 & 6.026 & 3.026 \\
\hline Makurdi & 7.700 & 8.452 & 8.773 & 4.275 & 4.605 & 8.000 & 8.206 & 5.000 & 3.833 & 6.180 & 8.395 & 7.550 & 4.190 \\
\hline Lokoja & 8.800 & 10.167 & 10.000 & 5.068 & 6.500 & 10.214 & 9.775 & 5.500 & 4.806 & 8.225 & 10.095 & 8.063 & 4.958 \\
\hline Minna & 9.617 & 10.904 & 10.692 & 6.640 & 7.750 & 10.750 & 10.391 & 7.000 & 6.452 & 9.391 & 10.700 & 9.058 & 6.577 \\
\hline Bauchi & 10.333 & 11.093 & 11.630 & 6.981 & 7.625 & 11.313 & 11.479 & 8.152 & 7.114 & 9.458 & 11.577 & 10.481 & 7.093 \\
\hline Maiduguri & 11.850 & 12.741 & 13.222 & 8.596 & 9.100 & 12.580 & 13.292 & 9.848 & 8.478 & 10.917 & 12.827 & 12.037 & 8.630 \\
\hline Sokoto & 13.017 & 13.741 & 14.222 & 9.712 & 10.180 & 13.700 & 14.060 & 10.708 & 9.739 & 10.584 & 14.019 & 13.185 & 9.796 \\
\hline
\end{tabular}

Table 3. Comparison of Seasonal and Yearly Optimum Tilt Angles, $\mathrm{s}^{*}$ [Degree], (and Insolation on Tilted Surface, $\mathrm{q}_{\mathrm{s}}{ }^{*}\left[\mathrm{MJ} / \mathrm{m}^{2} \mathrm{day}\right]$ )

\begin{tabular}{|c|c|c|c|c|c|c|c|c|c|c|}
\hline \multirow{3}{*}{ Location } & \multirow{3}{*}{$\begin{array}{c}\text { Latitude } \\
{\left[{ }^{0} \mathbf{N}\right]}\end{array}$} & \multicolumn{6}{|c|}{ Seasonal } & \multicolumn{3}{|c|}{ Yearly } \\
\hline & & \multicolumn{2}{|c|}{ Present work } & \multicolumn{2}{|c|}{ Wenger \& Oliveira [13] } & \multicolumn{2}{|c|}{ Fagbenle [14] } & \multirow{2}{*}{$\begin{array}{c}\text { Present } \\
\text { work }\end{array}$} & \multirow{2}{*}{$\begin{array}{c}\text { Wenger \& } \\
\text { Oliveira } \\
{[13]}\end{array}$} & \multirow{2}{*}{$\begin{array}{c}\text { Fagbenle } \\
{[14]}\end{array}$} \\
\hline & & Harmattan & Rain & Harmattan & Rain & Harmattan & Rain & & & \\
\hline $\begin{array}{c}\text { Port } \\
\text { Harcourt }\end{array}$ & 4.858 & $\begin{array}{c}3.406 \\
(14.314)\end{array}$ & $\begin{array}{c}3.750 \\
(11.629)\end{array}$ & $\begin{array}{c}4.858 \\
(14.310)\end{array}$ & $\begin{array}{c}4.858 \\
(11.627)\end{array}$ & $\begin{array}{c}14.858 \\
(14.104)\end{array}$ & $\begin{array}{c}14.858 \\
(11.481)\end{array}$ & $\begin{array}{c}3.571 \\
(12.7972)\end{array}$ & $\begin{array}{c}4.858 \\
(12.970)\end{array}$ & $\begin{array}{c}14.858 \\
(12.794)\end{array}$ \\
\hline Enugu & 6.467 & $\begin{array}{c}5.028 \\
(16.022) \\
\end{array}$ & $\begin{array}{c}5.464 \\
(13.191) \\
\end{array}$ & $\begin{array}{c}6.467 \\
(16.018) \\
\end{array}$ & $\begin{array}{c}6.467 \\
(13.189) \\
\end{array}$ & $\begin{array}{c}16.467 \\
(15.786) \\
\end{array}$ & $\begin{array}{c}16.467 \\
(13.021) \\
\end{array}$ & $\begin{array}{c}5.219 \\
(14.607)\end{array}$ & $\begin{array}{c}6.467 \\
(14.604) \\
\end{array}$ & $\begin{array}{c}16.467 \\
(14.404)\end{array}$ \\
\hline Makurdi & 7.700 & $\begin{array}{c}6.550 \\
(17.677)\end{array}$ & $\begin{array}{c}6.765 \\
(15.018)\end{array}$ & $\begin{array}{c}7.700 \\
(17.674)\end{array}$ & $\begin{array}{c}7.700 \\
(15.016)\end{array}$ & $\begin{array}{c}17.700 \\
(17.428)\end{array}$ & $\begin{array}{c}17.700 \\
(14.815)\end{array}$ & $\begin{array}{c}6.474 \\
(16.345)\end{array}$ & $\begin{array}{c}7.700 \\
(16.342)\end{array}$ & $\begin{array}{c}17.700 \\
(16.105)\end{array}$ \\
\hline
\end{tabular}


Table 3. cont....

\begin{tabular}{|c|c|c|c|c|c|c|c|c|c|c|}
\hline \multirow{3}{*}{ Location } & \multirow{3}{*}{$\begin{array}{c}\text { Latitude } \\
{\left[{ }^{\circ} \mathbf{N}\right]}\end{array}$} & \multicolumn{6}{|c|}{ Seasonal } & \multicolumn{3}{|c|}{ Yearly } \\
\hline & & \multicolumn{2}{|c|}{ Present work } & \multicolumn{2}{|c|}{ Wenger \& Oliveira [13] } & \multicolumn{2}{|c|}{ Fagbenle [14] } & \multirow{2}{*}{$\begin{array}{c}\text { Present } \\
\text { work }\end{array}$} & \multirow{2}{*}{$\begin{array}{c}\text { Wenger \& } \\
\text { Oliveira } \\
{[13]}\end{array}$} & \multirow{2}{*}{$\begin{array}{c}\text { Fagbenle } \\
\text { [14] }\end{array}$} \\
\hline & & Harmattan & Rain & Harmattan & Rain & Harmattan & Rain & & & \\
\hline Lokoja & 8.800 & $\begin{array}{c}7.478 \\
(19.364)\end{array}$ & $\begin{array}{c}8.150 \\
(17.011)\end{array}$ & $\begin{array}{c}8.800 \\
(19.366)\end{array}$ & $\begin{array}{c}8.800 \\
(17.010)\end{array}$ & $\begin{array}{c}13.800 \\
(19.275)\end{array}$ & $\begin{array}{c}13.800 \\
(16.878)\end{array}$ & $\begin{array}{c}8.000 \\
(18.191)\end{array}$ & $\begin{array}{c}8.800 \\
(18.190)\end{array}$ & $\begin{array}{c}13.800 \\
(18.121)\end{array}$ \\
\hline Minna & 9.617 & $\begin{array}{c}8.423 \\
(21.301)\end{array}$ & $\begin{array}{c}9.174 \\
(19.216)\end{array}$ & $\begin{array}{c}9.617 \\
(21.298)\end{array}$ & $\begin{array}{c}9.617 \\
(19.215)\end{array}$ & $\begin{array}{c}14.617 \\
(21.202)\end{array}$ & $\begin{array}{c}14.617 \\
(19.147)\end{array}$ & $\begin{array}{c}8.979 \\
(20.292)\end{array}$ & $\begin{array}{c}9.617 \\
(20.291)\end{array}$ & $\begin{array}{c}14.617 \\
(20.215)\end{array}$ \\
\hline Bauchi & 10.333 & $\begin{array}{c}9.288 \\
(21.571)\end{array}$ & $\begin{array}{c}9.875 \\
(19.749)\end{array}$ & $\begin{array}{c}10.333 \\
(21.568)\end{array}$ & $\begin{array}{c}10.333 \\
(19.749)\end{array}$ & $\begin{array}{c}15.333 \\
(21.476)\end{array}$ & $\begin{array}{c}15.333 \\
(19.678)\end{array}$ & $\begin{array}{c}9.540 \\
(20.660)\end{array}$ & $\begin{array}{c}10.333 \\
(20.658)\end{array}$ & $\begin{array}{c}15.333 \\
(20.576)\end{array}$ \\
\hline Maiduguri & 11.850 & $\begin{array}{c}10.519 \\
(21.751)\end{array}$ & $\begin{array}{c}11.479 \\
(19.910)\end{array}$ & $\begin{array}{c}11.850 \\
(21.746)\end{array}$ & $\begin{array}{c}11.850 \\
(19.910)\end{array}$ & $\begin{array}{c}16.850 \\
(21.642)\end{array}$ & $\begin{array}{c}16.850 \\
(19.841)\end{array}$ & $\begin{array}{c}11.220 \\
(20.837)\end{array}$ & $\begin{array}{c}11.850 \\
(20.836)\end{array}$ & $\begin{array}{c}16.850 \\
(20.757)\end{array}$ \\
\hline Sokoto & 13.017 & $\begin{array}{c}11.593 \\
(22.025)\end{array}$ & $\begin{array}{c}12.340 \\
(20.161)\end{array}$ & $\begin{array}{c}13.017 \\
(22.019)\end{array}$ & $\begin{array}{c}13.017 \\
(20.160)\end{array}$ & $\begin{array}{c}18.017 \\
(21.827)\end{array}$ & $\begin{array}{c}18.017 \\
(20.080)\end{array}$ & $\begin{array}{c}11.942 \\
(20.903)\end{array}$ & $\begin{array}{c}13.017 \\
(20.900)\end{array}$ & $\begin{array}{c}18.017 \\
(20.807)\end{array}$ \\
\hline
\end{tabular}

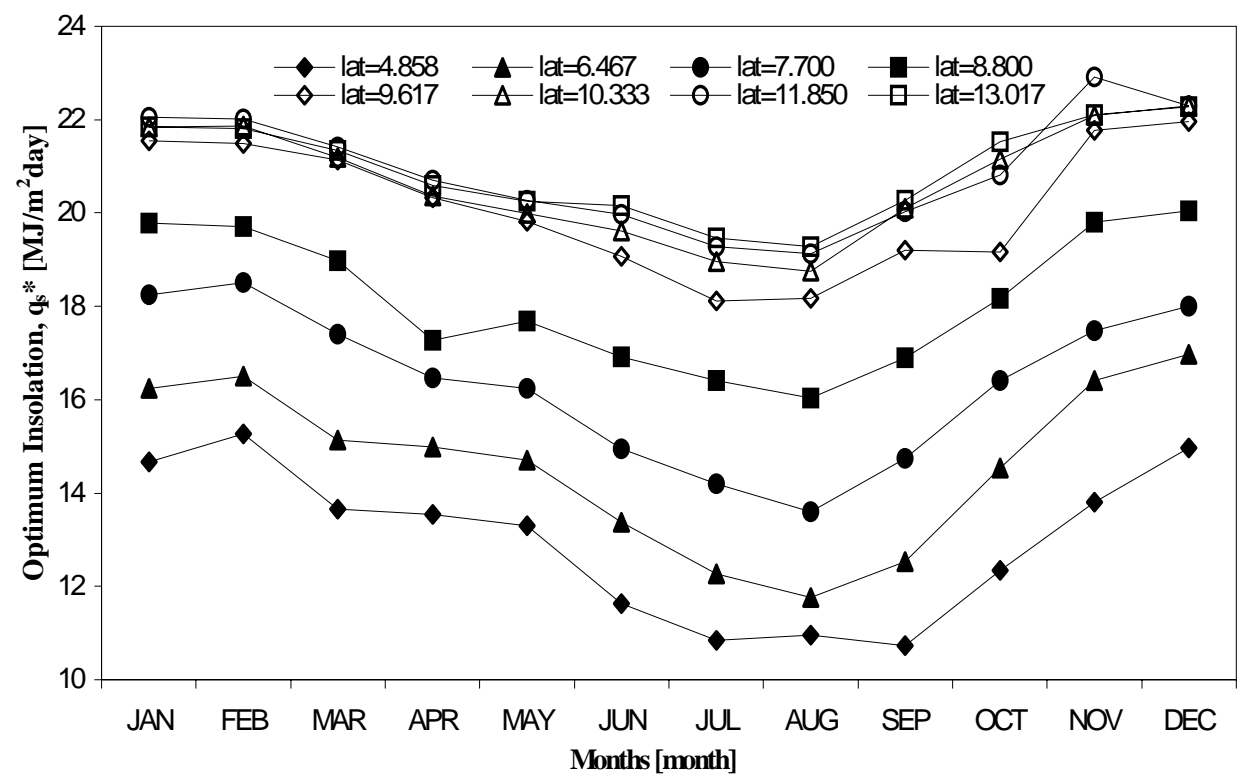

Fig. (7). Monthly average daily optimum insolation on a tilted surface for different latitudes $\left[{ }^{\circ} \mathrm{N}\right]$.

Table 4. Expression for the Monthly Optimum Tilt Angle Equation as a Function of the Latitude, $\phi\left[{ }^{0} \mathrm{~N}\right], 4.858<\phi<13.017$

\begin{tabular}{|c|c|c|}
\hline Month & Equation & ${\text { Regression Coefficient, } \mathbf{R}^{2}}^{2}$ \\
\hline \hline January & $\mathrm{s}^{*}=3.1731+1.8629 \phi-0.04360 \phi^{2}$ & 0.9952 \\
\hline February & $\mathrm{s}^{*}=0.0376+1.186 \phi-0.0069 \phi^{2}$ & 0.9934 \\
\hline March & $\mathrm{s}^{*}=2.8649+0.8606 \phi+0.0087 \phi^{2}$ & 0.9835 \\
\hline April & $\mathrm{s}^{*}=5.1027+1.5296 \phi-0.0271 \phi^{2}$ & 0.9919 \\
\hline May & $\mathrm{s}^{*}=3.2078+1.8402 \phi-0.04148 \phi^{2}$ & 0.9968 \\
\hline June & $\mathrm{s}^{*}=1.3594+1.3692 \phi-0.0131 \phi^{2}$ & 0.9877 \\
\hline July & $\mathrm{s}^{*}=0.7960+0.5101 \phi+0.0305 \phi^{2}$ & 0.9897 \\
\hline August & $\mathrm{s}^{*}=2.4705+0.6925 \phi+0.0198 \phi^{2}$ & 0.9760 \\
\hline September & $\mathrm{s}^{*}=8.1841+2.6203 \phi-0.0881 \phi^{2}$ & 0.9977 \\
\hline October & $\mathrm{s}^{*}=2.2886+1.6459 \phi-0.0304 \phi^{2}$ & \\
\hline
\end{tabular}


Table 4. cont....

\begin{tabular}{|c|c|c|}
\hline Month & Equation & ${\text { Regression Coefficient, } \mathbf{R}^{2}}^{0}$ \\
\hline \hline November & $\mathrm{s}^{*}=0.8236+0.6640 \phi+0.0227 \phi^{2}$ & 0.9925 \\
\hline December & $\mathrm{s}^{*}=2.2578+0.7214 \phi+0.0164 \phi^{2}$ & 0.9932 \\
\hline
\end{tabular}

Table 5. Expression for the Seasonal and Yearly Optimum Tilt Angle as a Function of the Latitude, $\phi\left[{ }^{\circ} \mathrm{N}\right], 4.858<\phi<13.017$

\begin{tabular}{|c|c|c|}
\hline Month & Equation & ${\text { Regression Coefficient, } \mathbf{R}^{2}}^{2}$ \\
\hline \hline Harmattan & $\mathrm{s}^{*}=3.9743+1.6770 \phi-0.0374 \phi^{2}$ & 0.9863 \\
\hline Rain & $\mathrm{s}^{*}=2.6136+1.3634 \phi-0.0156 \phi^{2}$ & 0.9981 \\
\hline Yearly & $\mathrm{s}^{*}=2.9489+1.4050 \phi-0.0190 \phi^{2}$ & 0.9965 \\
\hline
\end{tabular}

This facilitates the prediction of the optimum tilt angles (monthly, seasonal and yearly) for any location within the range of low latitudes covered in this work.

\section{CONCLUSION}

The monthly, seasonal and yearly optimum flat plate solar collector tilt angles for low latitudes, 4.86-13.02 ${ }^{\circ} \mathrm{N}$, have been presented in this work. Graphical and tabular data were generated, and polynomial expressions correlating the optimum tilt angle with the latitude were presented. The results, which have been shown to be better than those in the literature, will be particularly useful to the low-latitude solar equipment design engineers. Similar approach can be adopted for obtaining the optimum tilt angles for latitudes outside the range considered in this work.

\section{CONFLICT OF INTEREST}

None declared.

\section{ACKNOWLEDGEMENT}

None declared.

\section{REFERENCES}

[1] Sandler, J.S.; Colin, P.L.; Kelly, M.; Fenical, W. Cytotoxic macrolides from a new species of the deep-water marine sponge Leiodermatium. J. Org. Chem., 2006, 71 (22), 7245-7251.

[2] Howell, J.R.; Bannerot, R.B.; Vliet, G.C. Solar-thermal energy systems-analysis and design, McGraw-Hill: New York, 1982.
[3] Coppolino, S. A simple model for computing diffuse solar radiation. Solar Energy, 1989, 43 (6), 385-389.

[4] Ideriah, F.J.K. A model for calculating direct and diffuse solar radiation. Solar Energy, 1981, 1 (26), 447-452.

[5] Ideriah, F.J.K. On the relationship between diffuse and global solar radiation. Solar Energy, 1983, 31 (1), 119-124.

[6] Ideriah, F.J.K.; Suleman, S.O. Sky condition at Ibadan during 1975 - 1980, Solar Energy, 1989, 43 (6), 325-330.

[7] Duffie, J.A.; Beckman, W.A. Solar energy thermal processes, John wiley and Spons Inc.: New York, 1974.

[8] Shariah, A.; Al-Akhras, M.A.; Al-Omari, I.A. Optimizing the tilt angle of solar collectors. Renew. Energy., 2002, 26, 587-598.

[9] Ulgen, K. Optimum tilt angle for solar collectors. Energy. Sources., 2006, 28, 1171-1180.

[10] Gunerhan, H.; Hepbasli, A. Determination of the optimum tilt angle of solar collectors for building applications. Build. Env., 2007, 42, 779-783.

[11] Ertekin, C.; Evrendilek, F.; Kulcu, R. Modeling spatio-temporal dynamics of optimum tilt angles for solar collectors in turkey, Sensors, 2008, 8, 2913-2931.

[12] Markvart, T. Solar Electricity. Wiley: United Kingdom, 1994.

[13] Ahmad, M.J.; Tiwari, G.N. Optimization of tilt angle for solar collector to receive maximum radiation. The. Open. Renew. Energy J., 2009, 2, 19-24.

[14] Wenger, M.E. and Oliveira, L.C. (2004). Solar kiln design 1-solar heated dry kiln Available at: http://www.woodweb.com knowledge_base/solar_kiln_designs1.htm [accessed January 29, 2010].

[15] Fagbenle, R.L. Optimum collector tilt angles and annual global radiation for Nigerian locations. Nigerian J. Renew. Energy, 1991, 2 (17), 1-8.

[16] Qiu, G.; Riffat, S.B. Optimum tilt angle of solar collectors and its impact on performance. Int. J. Ambient. Energy., 2003, 24, 13-20.

[17] Liu, B.Y.H.; Jordan, R.C. The interrelationship and characteristic distribution of direct diffuse and total solar. Solar Energy, 1960, 4 (3), 1-19. 